\title{
Charleston Conference 2012 Proceedings
}

\section{Using Your Library's Annual Report to Market Library Services}

Corey Seeman, Director, Kresge Business Administration Library, Ross School of Business of the University of Michigan, cseeman@umich.edu ABSTRACT: This presentation discussed how the annual report can be an important element in a library's marketing program rather than a chore that needs to be accomplished each year. While not every library produces an annual report, the data that goes into a report is often collected for a variety of functions and purposes already (ARL Stats, budget requests, organizational reports, etc.). By creating even a modest annual report, the library provides another mechanism to share its accomplishments and connect with both its user base and its governing body. It also helps demonstrate $\mathrm{ROI}$ (Return on Investment) for the library to its governing bodies (be they academic institutions, communities, corporations, etc.)

The Kresge Business Administration Library at the University of Michigan ${ }^{1}$ is an independent library, receiving its funding from the Ross School of Business. As a departmental library that receives funding outside the main library system, there is a perception that we have to work harder to show and demonstrate our ROI to the Dean's Office who make the financial allocations for the school. While a departmental library, we are a major operation with 21 staff members (including 8 librarians), 108 service hours a week as we serve a population of around 3700 FTE faculty, staff and students.

Historically, Kresge Library reported to different positions at the Ross School of Business. Typically, we reported to rotating Associate Deans. From 2006-2007 and 2010-present, we reported to the Chief Administrative Officer of the school. The challenge for our library (and any department that reports to different people over the years) is that all administrators had different information they wanted and metrics that they considered important. One Associate Dean who oversaw the library was a "numbers" person and it led to Kresge staff counting just about everything we did. The presenter joined the library in 2005 and became the director in 2006. As a new director, I wanted to be able to showcase what we are doing and share that information with the school. This was driven in large part through conversations with leaders at the school who did not fully understand the scope of our operations and function at the school. Many people knew the library well - but only where their needs intersect with the library. For other work of the library, they had no idea of what we were accomplishing. In business terms, we needed to demonstrate that we provided excellent ROI or Return on Investment. And as Howes \& Zimmerman recently wrote in a recent CRL News, the key values of a departmental library is: proximity, flexibility, quality of service, and learning \& retention ${ }^{2}$. The annual report for us is a means to showcase all of these attributes of our library.

\footnotetext{
${ }^{1}$ For more information, please see http://tinyurl.com/KresgeLibrary

${ }^{2}$ Howes \& Zimmerman, The case for preserving academic branch libraries, College \& Research Libraries News vol. 72 no. 9 542-543 (2011)
} 
While there was no immediate history of an annual report at Kresge, we decided to move forward as a way to educate the school about what we accomplish on a regular basis at Kresge. We did not take this move without realizing that we already had all of the raw data to easily create an annual report for our community. We had been creating three documents that all told the story of Kresge and made the process of creating a public annual report much easier. First, we created an annual report for the ABLD (Academic Business Library Directors) that were shared with the top 50 business libraries in North America. While for a library audience, the report for ABLD focused on services, collections and staff issues. Second, we would create a cover letter for our annual budget request that recounted our accomplishments and the basis for our budget request. Third, we compiled collection and use statistics for Michigan's ARL report (where our numbers are added to the rest of the University Library).

In creating our annual report, we set a number of goals to make this a useful document. First, we wanted to present the information for the Ross audience by removing library jargon. Second, we wanted to present an overview of what we are doing at Kresge that is both good and no so good. Third, we wanted to focus on our collections and activities, not create a document that would primarily be used for fundraising. Lastly, I wanted to share the spotlight with our entire staff at the library by including their names and individual accomplishments. We also wanted to balance between sharing outputs (circulation, downloading, transactions, etc.) and how we help support students and faculty outcomes (how people use our resources in classes, clubs, and their career search). We also wanted the reports to be low cost, web based and very easy to find older reports.

Given that we were doing this independently, we were not bound by any rules or conventions. This freed us to having to follow a set format and the web-based approach allowed us to work independent from what would print well. The basic structure of the report is as follows: library initiatives \& operations, collections news, Kresge Library by the numbers, library staff news, presentations and articles \& staff listing. While we talk about the financial situation of the library, especially in the light of budget cuts over the last few years, we do not provide a full financial statement. Instead, we focus on our activities and accomplishments. The size of the report varies from 6 pages in 2007 to 10 pages in 2011 . Fundamentally, the document is as long as it needs to be and released when it is ready.

When the annual report is finished, it is released to the school in a number of means. First, we email the document (as a link) to all the faculty, staff and students at the Ross School of Business. Second, we use this for recruiting events for Kresge librarians, staff and supervisors (who are all Michigan School of Information students). Third, we use this for faculty and $\mathrm{PhD}$ recruiting as well when we are engaged in those processed. Additionally, we were able to use the report to reach out to people who are new to the school, such as our new Dean who was appointed earlier in 2011. Besides sharing our activities with the Ross Community, the annual report also showcases the full scope of our work. I have heard from many faculty that they were not aware that we were active in the library profession with presentations and articles (especially from a 
non-tenure shop). In addition, we were able to share information such as a Fullbright appointment for a library, non-library activities at Kresge (2011 spring food drive), and others.

Ultimately, we use the annual report to make many small connections with the school that showcase what we can accomplish at the library. Upon sending the report out this year, we received a question from a sophomore asking about our Embedded Librarian program and how it might be helpful for a student organization that is focused on consulting with organizations and companies (an important career path for business students). Through the mention of our services in our annual report, we are now working with another group of students on projects that enhance their education. If this is not one of the best outcomes of marketing, I am not sure what is. 